\title{
Histoarchitectural Features of the Hepatopancreas of the Amazon River Prawn Macrobrachium amazonicum
}

\author{
Histoarquitectura del Hepatopáncreas del Camarón de la Amazonia Macrobrachium amazonicum \\ "Irene Bastos Franceschini-Vicentini; "* Karina Ribeiro; "Luciene Patrici Papa; \\ "*Júlio Marques Junior; "Carlos Alberto Vicentini \& ****Patrícia Maria Contente Moraes Valenti
}

FRANCESCHINI-VICENTINI, I. B.; RIBEIRO, K.; PAPA, L. P.; MARQUES JUNIOR, J.; VICENTINI, C. A. \& VALENTI, P. M. C. M. Histoarchitectural features of the hepatopancreas of the Amazon river prawn Macrobrachium amazonicum. Int. J. Morphol., 27(1):121-128, 2009.

SUMMARY: In decapod crustaceans, the digestive gland is concerned with the digestion, absorption of nutrients, the storage of reserves and excretion. The metabolism and the histological and histochemical changes of the hepatopancreas are observed in response to physiological demands as moult, reproduction, digestive process. Thus the hepatopancreas structure should be recognized to provide important morphological information to future studies involving the nutrition requirements of freshwater prawn culture. In this study, second-generation Macrobrachium amazonicum produced from wild broodstock collected in the state of Pará in Brazil were used. Thirty adult male and female M. amazonicum were selected and randomly transferred to five experimental units for macroscopic and microscopic studies. The hepatopancreas of M. amazonicum is a large, yellowish-brown, compact organ, which occupies much of the cephalothoracic cavity. It has right and left halves that are enclosed together in a laminar connective tissue capsule, and at the same time they are separated by an interstitial connective tissue. The two halves are thereby called the right and left hepatopancreatic lobes. The principal tubule gives rise to four secondary tubules at each hepatopancreatic lobe. The morphological and functional unit consists of a blind-ended hepatopancreatic tubule, considered in the present study as the hepatopancreatic lobule. Each hepatopancreatic tubule can be subdivided into distal, medial and proximal zones. The hepatopancreatic tubule is lined by a pseudostratified epithelium that consists of five different cell types, which include the E-cell (embryonic), F-cell (fibrillar), B-cell (blister-like), R-cell (resorptive) and M-cell (midgut or basal). It is important to emphasize that the function of each cell type in the hepatopancreas during the digestive cycle is not yet established for decapods.

KEY WORDS: Hepatopancreas; Morphology; Decapoda; Macrobrachium amazonicum.

\section{INTRODUCCIÓN}

Decapod crustaceans have a digestive gland associated to the midgut. It has received different names from which hepatopancreas is the most accepted (Van Weel, 1974). The hepatopancreas is concerned with the digestion, absorption of nutrients, storage of reserves and excretion (Johnston et al., 1998; Sousa \& Petriella, 2000). It is also involved in the synthesis of digestive enzymes (Icely \& Nott, 1992). In general, the organ occupies much of the cephalothoracic cavity and is connected to the pyloric stomach by two primary ducts. Each duct branches into many hepatopancreatic tubules, which comprise the hepatopancreas (Johnston et al.; Souza \& Petriella). Each hepatopancreatic tubule consists of different cell types, which include the E-cell (embryonic), R-cell (resorptive), F-cell (fibrillar), B-cell (blisterlike) and M-cell (midget or basal) (Gibson \& Barker; Al-Mohanna \& Nott, 1987, 1989; Caceci et al., 1988; Icely \& Nott). The different cellular types have specific roles in the cyclical digestive process (Hirsch \& Jacobs, 1992; Gibson \& Barker; Sousa \& Petriella). The metabolism and the histological and histochemical changes

\footnotetext{
* Department of Biological Sciences, Faculty of Sciences, São Paulo State University (UNESP), Bauru, SP, Brazil and Aquaculture Center, CAUNESP/ UNESP, Jaboticabal, SP, Brazil.

** Department of Biochemistry, Laboratory of Enzimology, Federal University of Pernambuco, Recife, PE, Brazil and Aquaculture Center, CAUNESP/ UNESP, Jaboticabal, SP, Brazil.

${ }^{* * * *}$ Aquaculture Center, CAUNESP/UNESP, Jaboticabal, SP, Brazil.

This work was supported by a Grant of the Conselho Nacional de Desenvolvimento Científico e Tecnológio - CNPq (140151/2003-6 and 131456/2004-0).
} 
of the hepatopancreas are observed in response to physiological demands: moult, reproduction, digestive process (Icely \& Nott; Vogt et al., 1985; Johnston et al.). Thus, the hepatopancreas structure should be recognized to provide important morphological information to future studies involving the nutrition requirements of freshwater prawn culture.

Macrobrachium amazonicum is widely distributed in estuaries and mainly interior areas, from Venezuela to Argentina. In North and Northeast Brazil, M. amazonicum is very important to artisan fisheries (New, 2000), and is the South American prawn with the greatest potential for aquaculture (New, 2005). In 2000, a multidisciplinary and multi-institucional program was begun to development a sustainable technology to produce $M$. amazonicum (Valenti et al., 2003), in which this work is inserted.

Considering the above rationale, the present study evaluated the structural characteristics of the M. amazonicum hepatopancreas to provide the framework for nutrition requirement research that is applied to the development of commercial diets for prawn culture.

\section{MATERIAL AND METHOD}

Second-generation $M$. amazonicum produced from wild broodstock collected in the state of Pará in Brazil was used in this study. The animals were reared in the broodstock ponds of the Crustacean Sector, Aquaculture Center at São Paulo State University, SP, Brazil. Thirty adult male and female $M$. amazonicum were selected and randomly transferred to five experimental units (six individuals per experimental unit). Each experimental unit consisted of a 1000-L tank which was provided with aeration and a 10-L biological filter. Water was continuously circulated through the biological filter to maintain low levels of ammonia and nitrite. Temperature was maintained $28.5 \pm 1.5 \mathrm{C}$ by heaters.

The animals were maintained in the experimental units and received no food for $48 \mathrm{~h}$. After this period, they were killed by thermal shock. For macroscopic studies, 10 animals had their cephalothoracic cavity opened and the hepatopancreas dissected and analyzed. For microscopic studies, 10 animals had their hepatopancreas removed, fixed in $10 \%$ buffered formalin and embedded in Historesin (Leica, Germany). The histological sections were stained with hematoxylin-eosin and $1 \%$ toluidine blue. The material was analyzed and photodocumented with an Olympus DP-12 digital camera coupled to an Olympus B-MAX 50 microscope (Olympus, Japan).
For microscopic studies of the junction of the stomach and hepatopancreas, 10 animals were injected with India ink via the stomach in order to label the circulation of the fluids inside the hepatopancreas. After this, the stomach and midgut (hepatopancreas and intestine) were removed and fixed in Bouin's fluid for $48 \mathrm{~h}$, and then embedded in paraplast (Oxford, USA). Longitudinal sections (15 $\mu \mathrm{m}$ thick) were stained with hematoxylin-eosin. The sections were analyzed with an Olympus BX-50 microscope (Olympus, Japan).

\section{RESULTS}

The hepatopancreas is a large, yellowish-brown, compact organ, which occupies much of the cephalothoracic cavity, posterior to the cardiac portion of the stomach. It has two separate halves, which are connected ventrally to the midgut at the junction of the stomach and at the midgut by a principal tubule. At the hepatopancreatic gastric junction, the lining pseudostratified epithelium of the stomach ends abruptly, and the absorptive and secretory pseudostratified epithelium of the hepatopancreatic principal tubule begins (Fig. 1). The right and left halves are enclosed together in a laminar connective tissue capsule, and at the same time they are separated by an interstitial connective tissue that constitutes a thin fibrous septum. The right and left halves are not connected to each other, but they are connected separately to the intestine through the corresponding principal tubule. The right and left halves are thereby known as right and left hepatopancreatic lobes in M. amazonicum. The principal tubule gives rise to four secondary tubules at each hepatopancreatic lobe (Fig. 1). The dorsal and ventral secondary tubules derive from the medial portion of the principal tubule (Fig. 1). The cranial and caudal secondary tubules originate at their respective portions of the principal tubule (Fig. 1). The secondary tubules branch extensively into blind-ended hepatopancreatic tubules (Figs. 1 and 2A).

The morphological and functional unit consists of a blind-ended hepatopancreatic tubule, considered in the present study as the hepatopancreatic lobule (Fig. 2A). Each hepatopancreatic tubule can be subdivided into distal, medial and proximal zones relative to the distance from the midgut, and is surrounded by laminar connective tissue and myoepithelial cells (Fig. 2A). The epithelial lining rests on a thin but distinct basal membrane, which forms the boundaries of the hemolymph spaces between tubules (Fig. 2A). The hepatopancreatic tubule is lined by a pseudostratified epithelium that consists of five different cell types, which include the Ecell (embryonic) (Figs. 2A and B), F-cell (fibrillar) (Figs. 2C and D), B-cell (blisterlike) (Figs. 2A and D), R-cell (resorptive) (Figs. 2A and C), and M-cell (midgut or basal) (Fig. 2E). 


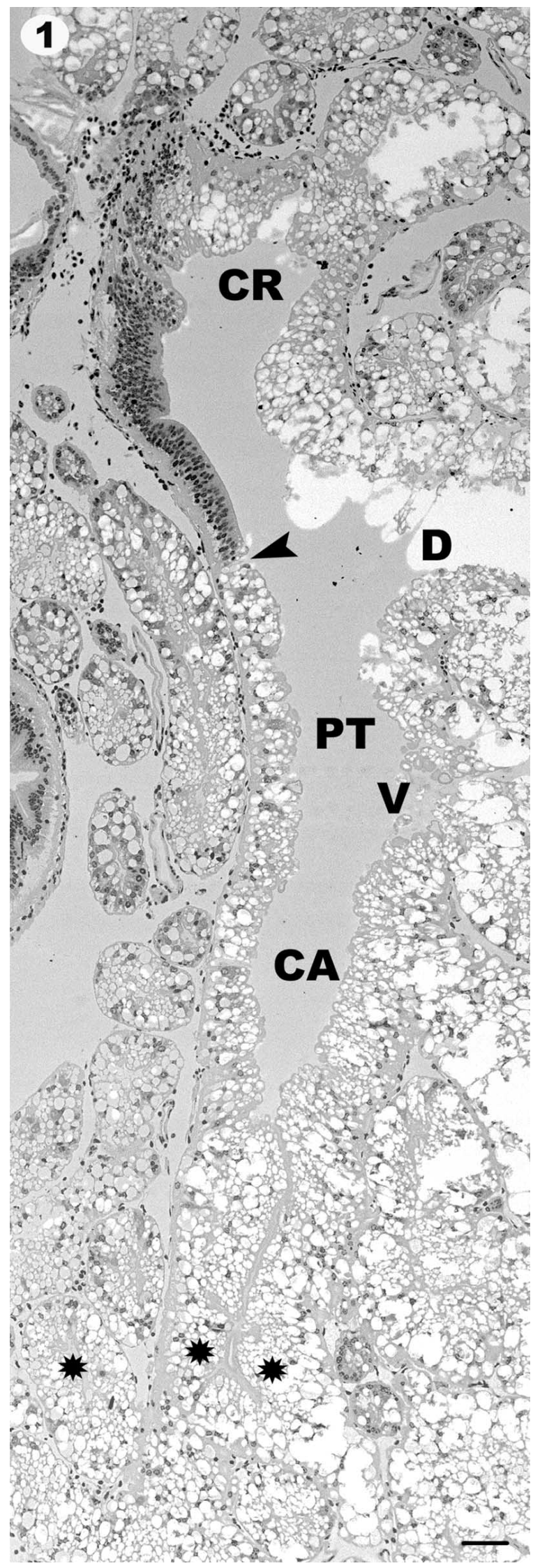

Fig. 1. Histological section of Macrobrachium amazonicum hepatopancreas (H/E). The principal tubule gives rise to the cranial, dorsal, ventral and caudal secondary tubules. The secondary tubules branch extensively into blind-ended hepatopancreatic tubules. At the hepatopancreatic gastric junction, the lining pseudostratified epithelium of the stomach ends abruptly, and the absorptive and secretory pseudostratified epithelium of the hepatopancreatic principal tubule begins (arrowhead). Abbreviations: PT, principal tubules; CR, cranial secondary tubule; D, dorsal secondary tubule; V, ventral secondary tubule; CA, caudal secondary tubule; asterisks, blind-ended hepatopancreatic tubule; arrowhead, hepatopancreatic gastric junction. Scale bar $=100 \mu \mathrm{m}$.

E-cells are cuboidal and undifferentiated and undergo cell division (Fig. 2B). They have a round and prominent nucleus that occupies most of the basophilic cytoplasm, lack brush border and are mainly located at the distal zone of the hepatopancreatic tubules (Fig. 2B). F-cells are cylindrical or triangular with a round apical region that is prominent in the lumen and have a brush border (Fig. 2C). A round nucleus is located towards the central or basal region of the cell (Fig. 2C). F-cells have a basophilic cytoplasm (Fig. 2C) and are situated at the medial and proximal zones of the hepatopancreatic tubules.

B-cells are the largest cell type in the hepatopancreas and have a large vacuole encompassed by a thin layer of cytoplasm (Fig. 2D). The nucleus is restricted to the basal region of the cell and the apical cytoplasm contains numerous small vacuoles (Fig. 2D). Sometimes, these small vacuoles seem to be released by apocrine secretion. B-cells are more abundant at the medial and distal zones of the hepatopancreatic tubules.

$\mathrm{R}$-cells are the most numerous cell types in the hepatopancreas. They are cylindrical and have a conspicuous brush border (Fig. 2C). They contain characteristic subapical vacuoles, and the nucleus lies toward the basal region of the cell (Fig. 2C). $\mathrm{R}$-cells occur throughout most of the medial and proximal tubular zones.

M-cells comprise the least numerous hepatopancreatic cell types. They have a triangular shape with a round apical outline and do not appear to have a brush border, as they have no direct contact with the lumen (Fig. 2E). The cytoplasm is basophilic and contains a round central nucleus (Fig. 2E). M-cells are scattered throughout most of the length of the hepatopancreatic tubule.

F-cells are less frequent and are scattered between B and R-cells along the length of the medial and proximal tubular zones. All the hepatopancreatic tubules are lined with a pseudostratified epithelium with the same cell types. The stratified columnar epithelium of the pyloric stomach abruptly changes to the pseudostratified epithelium of the principal tubule of the hepatopancreas (Fig. 1). 

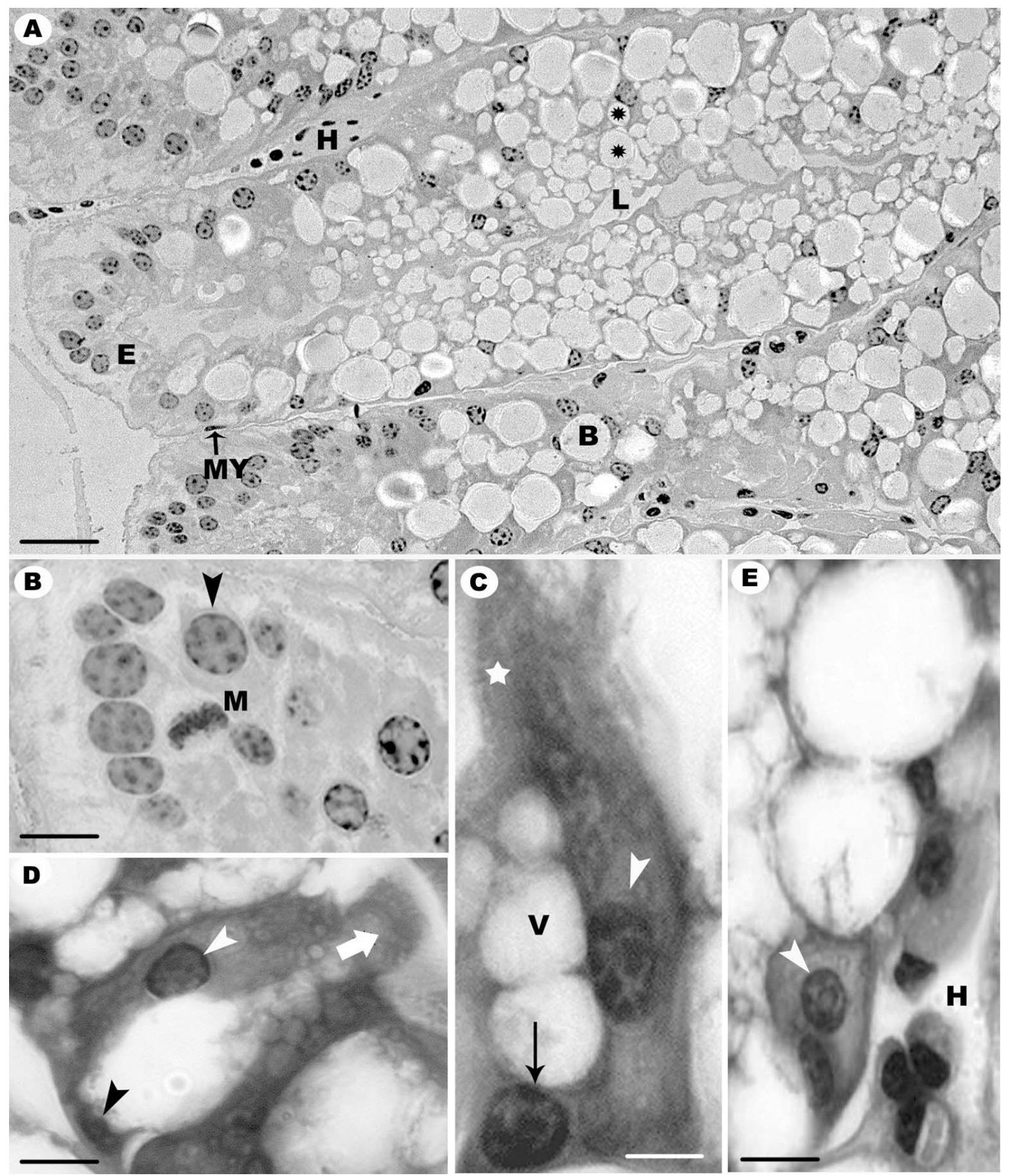

Fig. 2. Histological section of Macrobrachium amazonicum hepatopancreas (H/E). (A) The lumen of the secondary hepatopancreatic tubules is surrounded by laminar connective tissue and myoepithelial cells. The epithelial lining rests on a thin but distinct basal membrane which forms the boundaries of the hemolymph spaces between tubules. The hepatopancreatic tubuleis lined by a pseudostratified epithelium showing E-cell, B-cell and R-cell; (B) E-cells are cuboidal with a round nucleus (arrowhead) and undergo cell division; (C) R-cell is cylindrical with subapical vacuoles and the nucleus is located at the basal region of the cell. F-cell is cylindrical with a round apical region that is prominent in the lumen and has a brush border. The nucleus is centrally located. (D) B-cell has a large vacuole encompassed by a thin layer of cytoplasm. The nucleus is restricted to the basal region of the cell and the apical cytoplasm contains numerous small vacuoles that seem to be released by apocrine secretion. F-cell has a basophilic cytoplasm and a round nucleus; (E) M-cell has a triangular shape with a round central nucleus. The hemolymph space is observed between hepatopancreatic tubules. Abbreviations: L, lumen; MY, myoepithelial cell; $\mathrm{H}$, hemolymph spaces; E, E-cell; B, B-cell; asterisks, R-cell; arrowhead, nucleus; M, cell division; V, subapical vacuoles; thin arrow, nucleus; thick arrow, apocrine secretion; star, brush border. Scale bar in $\mathrm{A}=40 \mu \mathrm{m}$, in $\mathrm{B}=10 \mu \mathrm{m}$, in $\mathrm{C}=4 \mu \mathrm{m}$, in $\mathrm{D}=8 \mu \mathrm{m}$ and in $\mathrm{E}=4 \mu \mathrm{m}$. 
FRANCESCHINI-VICENTINI, I. B.; RIBEIRO, K.; PAPA, L. P.; MARQUES JUNIOR, J.; VICENTINI, C. A. \& VALENTI, P. M. C. M. Histoarchitectural features of the hepatopancreas of the Amazon river prawn Macrobrachium amazonicum. Int. J. Morphol., 27(1):121-128, 2009.

\section{DISCUSSION}

The hepatopancreas is morphologically similar in most decapods (Gibson \& Barker; Al-Mohanna \& Nott, 1987; 1989; Caceci et al.). However, there is little information available about this organ in caridean prawns. The number of hepatopancreatic lobes may vary in different species (Icely \& Nott). In M. amazonicum, only one lobe was observed in each half of the hepatopancreas. According to what is defined as a lobe in anatomical literature (Drake et al., 2005), in $M$. amazonicum there is a thin fibrous septum between the right and left halves. This septum subdivides the compact hepatopancreas into right and left lobes, and no other subdivision is observed in the hepatopancreatic parenchyma, except the connective tissue that surrounds the hepatopancreatic tubules. Similar results are described for Penaeus spp. (Vogt, 1992; Lovett \& Felder, 1989) and Caridina leaves (Pillai, 1992). However, in Homarus americanus (Icely \& Nott), the hepatopancreas is described as having three lobes, each one covered by an outer layer of connective tissue, on each side of the body (Factor \& Naar, 1985). The lobes of the hepatopancreas of M. amazonicum constitute a compact organ, but in Astacus astacus each lobe consists of an open network of tubules (Vogt et al., 1989).

In relation to the junction of the hepatopancreas with the stomach, in M. amazonicum a large principal tubule is observed in each half. This standard connection corroborates the existence of right and left lobes in M. amazonicum. In Homarus americanus, each lobe has a major collecting duct, and on each side of the animal the three collecting ducts lead into the major collecting duct that empties into the midgut (Factor, 1981; Factor \& Naar, 1985).

The characterization of the hepatopancreatic lobule of $M$. amazonicum is defined on the basis of the wellestablished counterpart in vertebrates (Ross \& Pawlina, 2006). In vertebrates, the hepatic lobule constitutes the morphological and functional unit of the liver, and it is individualized by connective tissue. In M. amazonicum, the morphological and functional unit corresponds to the hepatopancreatic tubule, which is also called here the hepatopancreatic lobule. The hepatopancreatic lobule in $M$. amazonicum is surrounded by a loose connective tissue that delimits the hemolymph sinuses which occupy most of the intertubular space. A similar morphological pattern has been observed in several decapods (Al-Mohanna et al., 1985; AlMohanna \& Nott, 1987, 1989; Icely \& Nott; Souza \& Petriella), although the term hepatopancreas lobule has never been mentioned.

Four cell types have been consistently identified in the epithelium of the decapod hepatopancreas. They are classified as E- (embryonic), R- (resorptive), F- (fibrillar) and B- (blisterlike) cells, according to the scheme proposed for the hepatopancreas of some decapods (Jacobs, 1992; Hirsch \& Jacobs). In M. amazonicum, a fifth cell type is present, the M-cell. M-cells have been observed in the hepatopancreatic tubule of $P$. semisulcatus (Al-Mohanna et al., 1985; Al-Mohanna \& Nott, 1987; 1989) and $H$. americanus (Icely \& Nott). However, M-cells are not present in the hepatopancreatic epithelium of Astacus astacus (Vogt et al., 1989) and Palaemonetes argentinus (Souza \& Petriella). M-cells mature progressively toward to the proximal end of the hepatopancreatic tubule, but changes in structure are linked more with phases in the molt cycle rather than in the feeding cycle (Al-Mohanna \& Nott, 1987).

The locations of the cell types vary along the length of the hepatopancreatic tubules (Icely \& Nott). In $M$. amazonicum, E-cells are observed at the blind distal end and are involved in mitotic activity. These characteristics are coincident with those observed in decapod species (AlMohanna \& Nott, 1989; Petriella \& Fonalleras, 1998; Souza \& Petriella).

F-cells are found throughout the length of the hepatopancreatic tubules in M. amazonicum. They are easily observed in the distal region, next to the E-cells. In contrast, in $P$. semisulcatus (Al-Mohanna \& Nott, 1989) and $P$. vannamei (Caceci et al.), F-cells are observed only in the proximal and medial regions of the hepatopancreatic tubules. F-cells are described possessing a basophilic cytoplasm due to a high RNA content in $P$. argentinus (Souza \& Petriella). In $M$. amazonicum, the basophilic cytoplasm is very evident. This cell type has a high rate of protein synthesis and is the only site of digestive enzyme synthesis (Al-Mohanna \& Nott, 1989; Vogt et al., 1989; Johnston et al.).

B-cells are observed primarily in the medial and distal regions of the hepatopancreatic tubules of M. amazonicum. However, in P. semisulcatus, B-cells occur in the proximal region of the hepatopancreatic tubules (Al-Mohanna \& Nott, 1989). The presence of many apical pinocytotic vesicles and of a large central vacuole indicates that B-cells of $M$. amazonicum are involved in the absorption of nutrients from the hepatopancreatic tubular lumen. These pinocytotic capacities have been observed in P. semisulcatus (AlMohanna \& Nott, 1986, 1987), P. monodon (Vogt, 1993), Thenus orientalis (Johnston et al.), and P. argentinus (Souza \& Petriella). B-cells are responsible for intracellular digestion, concentrating the absorbed materials in the large vacuole (Al-Mohanna \& Nott, 1986), and secreting the vacuolar content at the end of the digestive process (Souza \& Petriella). The secretory mechanism is described as 
apocrine in Panulirus argus (Travis, 1992), merocrine or apocrine in Caridina laevis (Pillai, 1992) and holocrine in $P$. semisulcatus (Al-Mohanna \& Nott, 1989) and Palaemonetes argentinus (Souza \& Petriella). In M. amazonicum, the secretory mechanism of B-cells is described as apocrine. The apocrine secretion is probably due to the intracellular digestion of the nutrients and consequently extrusion of the digestive products into the tubular lumen. In the Centropagis typicus (Arnaud et al., 1978, 1984a, 1984b) and Calanus helgolandicus (Nott et al., 1985) at the end of the digestive process, B-cells disintegrate into the lumen, and it is believed that the digestion-derived nutrients are released for resorption by R-cells. However, B-cells of P. semisulcatus (Al-Mohanna \& Nott, 1986) and Botryllus schlosseri (Burighel \& Milanesi, 1977) have intracellular digestion, assimilation of the nutrients in the hemolymph, and elimination of the residual digestion products in the hepatopancreatic tubular lumen.

R-cells are the most common cell type in the hepatopancreatic tubules of $M$. amazonicum. These cells occur in the proximal and medial region of the tubules. In $P$. semisulcatus (Al-Mohanna \& Nott, 1989) and P. vannamei (Caceci et al.), R-cells are observed throughout the length of hepatopancreatic tubule. R-cells absorb nutrients from the lumen and function in the storage of lipid droplets and glycogen (Souza \& Petriella). These reserves can be mobilized to provide energy during periods of starvation, molting and reproduction (Al-Mohanna \& Nott, 1987). It is important to emphasize that the function of each cell type in the hepatopancreas during the digestive cycle is not yet established for decapods.

\section{ACKNOWLEDGEMENTS.}

This work was supported by a Grant of the Conselho Nacional de Desenvolvimento Científico e Tecnológio CNPq (140151/2003-6 and 131456/2004-0) and FUNDUNESP. We also thank Dr. Albert Leyva for English editing of the manuscript.

FRANCESCHINI-VICENTINI, I. B.; RIBEIRO, K.; PAPA, L. P.; MARQUES JUNIOR, J.; VICENTINI, C. A. \& VALENTI, P. M. C. M. Histoarquitectura del hepatopáncreas del camarón de la Amazonia Macrobrachium amazonicum. Int. J. Morphol., 27(1):121-128, 2009.

RESUMEN: La glándula digestiva en los crustáceos decápodos asume las funciones de digestión, absorción de nutrientes, almacenamiento de las reservas energéticas y excreción de metabolitos. El metabolismo y las alteraciones histológicas e histoquímicas son observados como respuesta a necesidades fisiológicas, tales como: muda, reproducción y procesos digestivos. Por lo tanto, se requiere conocer la estructura histológica del hepatopáncreas con el fin de reunir información morfológica para futuros estudios que consideren las necesidades nutricionales para el cultivo de los camarones de agua dulce. Fueran utilizados 30 animales, machos y hembras de Macrobrachium amazonicum, producidos a partir de reproductores colectados en el Estado de Pará, Brasil. Las observaciones macro y microscópicas permitieron concluir que el hepatopáncreas del M. amazonicum es un órgano grande y compacto de color amarillo tendiendo a marrón, que ocupa la mayor parte de la cavidad céfalo-torácica. El órgano presenta dos mitades, derecha y izquierda, las cuales están envueltas por una cápsula de tejido conjuntivo, y al mismo tiempo, separadas por tejido conectivo intersticial. Las dos mitades del órgano son identificadas como lobos derecho e izquierdo. Cada lobo presenta un túbulo principal que origina cuatro túbulos secundarios. Por lo tanto, la unidad morfofuncional del hepatopáncreas consiste en un túbulo hepatopancreático de fondo ciego, considerado en esta investigación como lóbulo hepatopancreático. Cada lóbulo hepatopancreático puede ser dividido en 3 regiones: distal, media y proximal, y en su totalidad, se observa revestido por epitelio seudo estratificado que reúne cinco tipos celulares: célula $\mathrm{E}$ (embrionaria), célula $\mathrm{F}$ (fibrilar), célula $\mathrm{B}$ (globosa), célula $\mathrm{R}$ (reabsortiva) y célula M (basal). Es importante enfatizar que la función de cada tipo celular del hepatopáncreas no está todavía aclarada para los decápodos.

PALABRAS CLAVE: Hepatopáncreas; Morfologia; Decápodo; Macrobrachium amazonicum.

\section{REFERENCES}

Al-Mohanna, S. Y.; Nott, J. A. \& Lane, D. J. W. M-“midget" cells in the hepatopancreas of the shrimp Penaeus semisulcatus de Haan 1844 (Crustacea:Natantia). Crustaceana, 48:260-8, 1985.
Al-Mohanna, S. Y. \& Nott, J. D. B-cells and ingestion in the hepatopancreas of Penaeus semisulcatus (Crustacea: Decapoda). J. Mar. Biol. Assoc. U. K., 66:403-14, 1986. 
FRANCESCHINI-VICENTINI, I. B.; RIBEIRO, K.; PAPA, L. P.; MARQUES JUNIOR, J.; VICENTINI, C. A. \& VALENTI, P. M. C. M. Histoarchitectural features of the hepatopancreas of the Amazon river prawn Macrobrachium amazonicum. Int. J. Morphol., 27(1):121-128, 2009.

Al-Mohanna, S. Y. \& Nott, J. D. M-"midget" cells and the moult cycle in Penaeus semisulcatus (Crustacea: Decapoda). J. Mar. Biol. Assoc. U. K., 67:803-13, 1987.

Al-Mohanna, S. Y. \& Nott, J. D. Function cytology of the hepatopancreas of Penaeus semisulcatus (Crustacea: Decapoda) during the moult cycle. Marine Biological, 101:535-44, 1989.

Arnaud, J.; Brunet, M. \& Mazza, J. Studies on the midgut of Centropages typicus (Copepod, Calanoid). Cell Tissue Res., 187:333-53, 1978.

Arnaud, J.; Brunet, M. \& Mazza, J. Détection d'une activité arylsulfatasique dasn les cellules B de I'intestin moyen de Centropages typicus (Copépode, Calanoide). Compte rendu hebdomadaire des séances le l'Académic des Sciences (ser III), 298:499-502, 1984a.

Arnaud, J.; Brunet, M. \& Mazza, J. Cytochemical detection of phosphatase and arylsulphatase activities in the midgut of Centropages typicus (Copepod, Calanoid). Basic Appl. Histochem., 28:399-412, 1984 b.

Burighel, P. \& Milanesi, C. Fine structure of the intestinal epithelium of the colonial ascidian Botryllus schlosseri. Cell Tissue Res., 182:357-69, 1977.

Caceci, T.; Neck, K. F.; Lewis, D. H. \& Sis, R. F. Ultrastructure of the hepatopancreas of the pacific white shrimp Penaeus vannamei (Crustacea:Decapoda). J. Mar. Biol. Assoc. U. K., 68:323-37, 1988.

Drake, R.; Vogl, W. \& Mitchell, A. W. M. Gray's Anatomy for Students. London, Churchill Livingstone, 2005.

Factor, J. R. Development and metamorphosis of the digestive cycle of larval lobsters, Homarus americanus (Decapoda: Nephropidae). J. Morphol., 169:225-58, 1981.

Factor, J. R. \& Naar, M. The digestive system of the lobsters, Homarus americanus: 1. Connective tissue of the digestive gland. J. Morphol., 184:311-21, 1985.

Gibson, R. \& Barker, P. L. The decapod hepatopancreas. Oceanogr. Mar. Biol. Annu. Rev., 17:285-346, 1979.

Hirsch, G. C. \& Jacobs, W. Der Arbeitsrhythmus der Mitteldarmdrüse von Astacus leptodactylus. I. Teil: Methodik und Technik, 1928. - In: Harrison, F. W. (Ed.), Microscopic Anatomy of Invertebrates, Volume 10. New York, Wiley-Liss, 1992. pp.147-201.
Icely, J. D. \& Nott, J. A. Digestion and Absorption: digestive system and associated organs. 1992. - In: Harrison, F. W. (Ed.), Microscopic Anatomy of Invertebrates, Volume 10. New York, Wiley-Liss, 1992.

Jacobs, W. Untersuchungen über die Cytologie der Seretbildung in der mitteldarmdrüse von Astacus leptodactylus. 1928. In: Harrison, F. W. (Ed.), Microscopic Anatomy of Invertebrates, Volume 10. New York, Wiley-Liss, 1992.

Johnston, D. J.; Alexander, C. G. \& Yellowhfes, D. Epithelial cytology and function in the digestive gland of Thenus orientalis (Decapoda, Scyllaridae). J. Crustacean Biol., 18:271-8, 1998.

Lovett, D. L. \& Felder, D. L. Ontogeny of gut morphology in the white shrimp Penaeus setiferus (Decapoda, Penaeidae). J. Morphol., 201:253-72, 1989.

New, M. B. Freshwater prawn farming: global status, recent research and a glance at the future. Aquaculture Res., 36:210-30, 2005.

New, M. B. History and global status of freshwater prawn farming. 2000. - In: New, M. B. \& Valenti, W. C. (Eds.), Freshwater Prawn Farming: The Farming of Macrobrachium rosenbergii. London, Blackwell Science Ltd., 2000. pp.1-11.

Nott, J. A.; Corner, E. D. S.; Mavin, L. J. \& O’Hara, S. C. M. Cyclical contributions of the digestive epithelium to faecal pellet formation by the copepod Calanus helgolandicus. Marine Biology, 89:271-9, 1985.

Petriella, A. M. \& Fonalleras, M. C. Citoaequitectura del hepatopancreas del camarón Artemesia longinaris Bate (Crustacea, Decapoda, Penaeidae). Physis, 55:25-30, 1998.

Pillai, R. S. Studies on the shrimp Caridina laevis (Heller). 1. The digestive system. 1960. In: Harrison, F. W. (Ed.), Microscopic Anatomy of Invertebrates, Volume 10. New York, Wiley-Liss, 1992.

Ross, M. H. \& Pawlina, W. Histology. A Text and Atlas. $5^{\text {th }}$ ed. Philadelphia, Lippincott Williams and Wilkins, 2006. p.906.

Sousa, L. G. \& Petriella, A. M. Histology of the hepatopancreas of the freshwater prawn Palaemonetes argentinus (Crustacea, Caridea). Biocell, 24:189-95, 2000 . 
FRANCESCHINI-VICENTINI, I. B.; RIBEIRO, K.; PAPA, L. P.; MARQUES JUNIOR, J.; VICENTINI, C. A. \& VALENTI, P. M. C. M. Histoarchitectural features of the hepatopancreas of the Amazon river prawn Macrobrachium amazonicum. Int. J. Morphol., 27(1):121-128, 2009.

Travis, D. The molting cycle of the spiny lobster Panulirus argus Latreille. IV. Post-ecdysial histology and histochemical changes in the hepatopancreas and integumental tissues. 1957. In: Harrison, F. W. (Ed.), Microscopic Anatomy of Invertebrates, Volume 10. New York, Wiley-Liss, 1992. pp.147-201.

Valenti, W. C., Franceschini-Vicentini, I. B. \& Pezzato, L. E. The potential for Macrobrachium amazonicum culture. In: Annals of the World Aquaculture. Baton Rouge, World Aquaculture Society, 2003. p.804.

Van Weel, P. B. Hepatopancreas?. Comp. Biochem. Physiol., 47:1-9, 1974.

Vogt, G. Differentiation of B-cells in the hepatopancreas of the prawn Penaeus monodon. Acta Zoologica, 74:5140, 1993.

Vogt, G. Histologie und Cytologie der Mittieldarmrüse von Penaeus monodon (Decapoda). 1985. In: Harrison, F. W. (Ed.), Microscopic Anatomy of Invertebrates, Volume 10. New York, Wiley-Liss, 1992.

Vogt, G.; Storch, V.; Quinitio, E. T. \& Pascual, F. P. Midgut gland as a monitor organ for nutritional value of diets in Penaeus monodon (Decapoda). Aquaculture, 48:1-12, 1985.

Vogt, G.; Stocker, W. \& Zwilling, R. Biosynthesis of Astacus proteases, a digestive enzyme from crayfish. Histochemistry, 91:373-81, 1989.
Correspondence to:

Irene Bastos Franceschini-Vicentini

Department of Biological Sciences

Faculty of Sciences, São Paulo State University (UNESP)

Bauru, SP, BRAZIL

Tel.: +55 14 3103-6078

Fax +55 14 3103-6092.

E-mail address: ibfv@fc.unesp.br

Received: 26-08-2008

Accepted: 02-12-2008 